\title{
Comparative Study of Metachromatic Staining Methods in Assessing the Exfoliative Cell Types During Oestrous Cycle in Sprague-Dawley Laboratory Rats
}

\author{
Estudio Comparativo de los Métodos de Tinción Metacromática en la Evaluación de los Tipos \\ de Células Exfoliativas Durante el Ciclo Estral en Ratas Sprague-Dawley de Laboratorio
}

\author{
Stephanie Mohammed ${ }^{1} \&$ Venkatesan Sundaram²
}

MOHAMMED, S. \& SUNDARAM, V. Comparative study of metachromatic staining methods in assessing the exfoliative cell types during oestrous cycle in Sprague-Dawley laboratory rats. Int. J. Morphol., 36(3):962-968, 2018.

SUMMARY: This study was aimed at comparing the commonly used metachromatic stains viz., Papanicolaou stain, WrightGiemsa, Toluidine blue and Methylene blue in the assessment of cell types of the oestrous cycle in rats. Eight female Sprague-Dawley rats aged 8-9 weeks were used for this assessment. Cotton Swabs were gently inserted in the animals vagina to obtain cells from which they were then transferred to glass slides for staining and evaluation under microscopy. The different cell types were compared for their morphological features and clarity of cellular detail under all four stains. The application, advantages and limitations of all stains were then discussed. It was concluded that the selection of the most effective stain in the assessment of vaginal cytology depends on their application to clinical or research which was based on the cellular detail of interest, time, cost and availability of each staining procedure.

KEY WORDS: Papanicolaou; Wright-Giemsa; Methylene blue; Toluidine blue; Vaginal cytology.

\section{INTRODUCTION}

In exfoliative vaginal cytology, epithelial cells undergo constant growth, shedding and replacement. The microscopic evaluation of these cells during exfoliation provides information on the stages of the cycle, possible infections, hormonal status and reproductive defects that might be occurring within the female reproductive system.

The short, regular but dynamic oestrous cycle of 45 days in rats has made them the ideal models for investigating the changes that occur in the reproductive system by vaginal exfoliative cytology (Cora et al. 2015). These morphological changes due to the desquamation depict four major phases of the oestrus cycle which include the Proestrus (P), Oestrous (O), Metestrous (M) and Diestrous (D) (Long \& Evans, 1922). Throughout the oestrous cycle, the major cells observed are small and large nucleated epithelial cells, anucleated, keratinized epithelial cells and neutrophils. The presence of bacteria and malignant cells are also identifiable during this process.

To properly assess the morphology and quantification of each cell type, various staining procedures are readily employed. The proper choice of stain and staining method is very crucial and selected based on the cellular detail of interest. The selection also depends on the collection of sample, fixation, nuclear staining, cytoplasmic staining and clearing (Ochei \& Kolhatkar, 2000). The most commonly used stains in the vaginal exfoliative cytology are Papanicolaou stain, WrightGiemsa, Toluidine blue and Methylene blue (Bancroft \& Stevens, 1996).

This present study is aimed at comparing the commonly used metachromatic stains viz., Wright-Giemsa, Toluidine blue, Methylene blue and Papanicolaou stain in the assessment of cell types of the oestrous cycle in rats.

\section{MATERIAL AND METHOD}

Eight female Sprague-Dawley rats aged 8-9 weeks

\footnotetext{
${ }^{1}$ Department of Preclinical Sciences, School of Medicine, Faculty of Medical Sciences, The University of The West Indies, Trinidad and Tobago. ${ }^{2}$ Department of Basic Veterinary Sciences, School of Veterinary Medicine, Faculty of Medical Sciences, The University of The West Indies, Trinidad.
} 


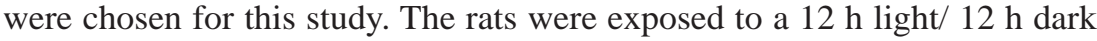
cycle with adequate food and water supply. All protocols involving the care and use of live animals for experimentation and code of ethics were followed and the work was approved by the institutional Ethical Committee.

The vaginal swabs from all rats were taken at 9 am daily for 15 days (three consecutive cycles and 120 vaginal swabs) to assess the oestrus cycle. The cotton swab technique was used in which the sterilized vaginal swabs were moist with saline, then inserted into the vagina, gently removing the cells from the vaginal lumen (Fig. 1) and then transferring onto a clear glass slide. The slides were then left to air-dry to get fixed for Wright-Giemsa, Toluidine blue and Methylene blue staining whereas the slides were fixed with $96 \%$ ethanol for 30 min for Panipacolaou (Pap) stain. All the slides were stained as per standard procedures (Suvarna et al., 2012; Cora et al.).

The slides were then observed and analysed for the assessment of each cell type and phase of the oestrous cycle and the digital images were obtained with the aid of the Olympus BX51 system microscope and the Olympus DP71 microscope digital camera.
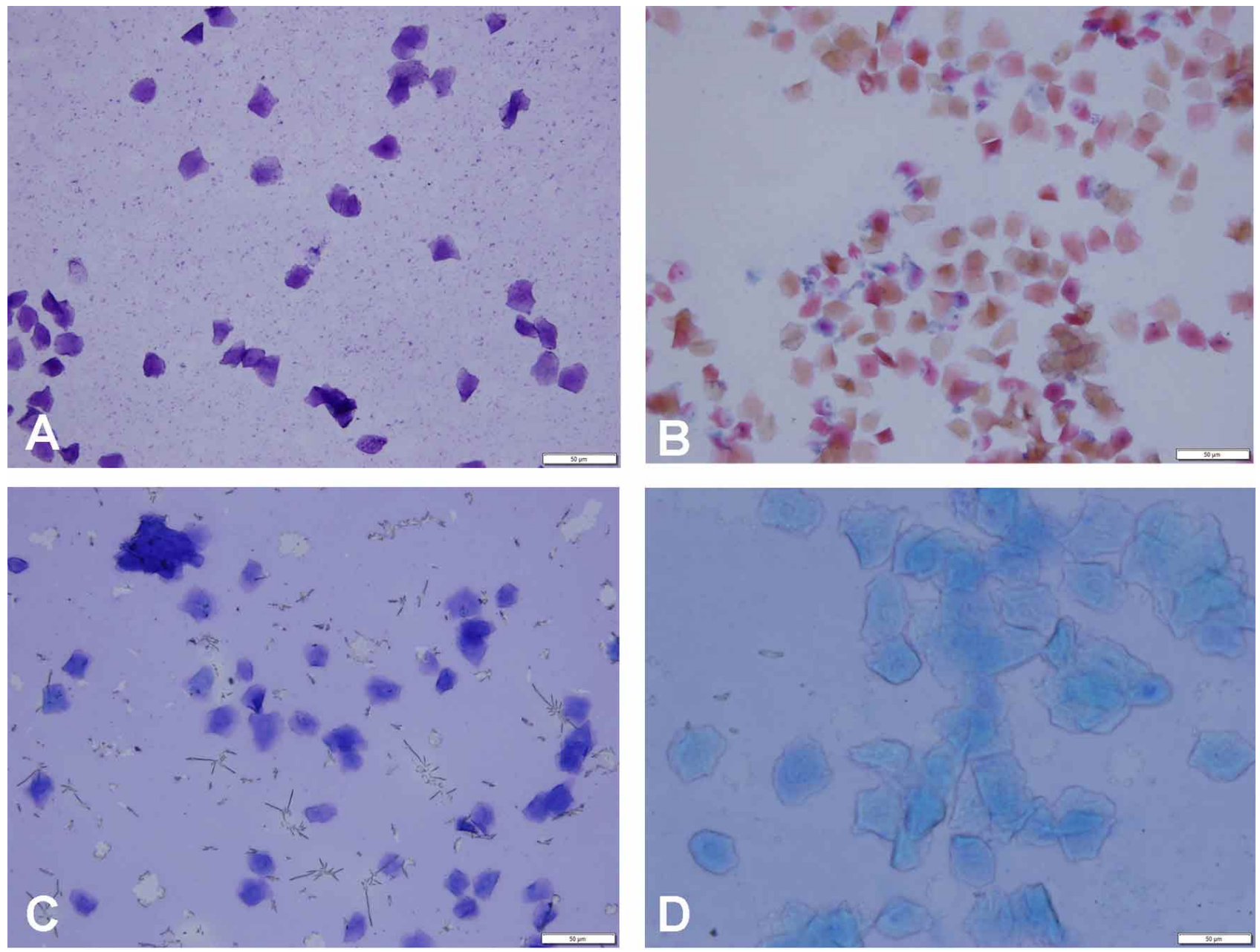

Fig. 2. Keratinized cells. Wrights-Giemsa stain (A), Pap Stain (B), Toluidine blue (C) and Methylene blue (D). 


\section{RESULTS}

Cell types of oestrous cycle: The following cell types were identified based on the cytomorphology during the oestrous cycle in the present study with the use of various metachromatic stains.

1. Anucleated keratinized cells. The anucleated keratinised cells were large, irregular shaped cornified cells with lack of visible nucleus (Fig. 2). All four stains gave proper clarity of cornified cells. Papanicolaou stain however was able to show the various shades of orange, pink and blue associated with level of cornification. The presence of bacteria was also noticed clearly with the use of toluidine blue in the present study.

2. Epithelial cells. The epithelial cells consisted of three major cells viz, parabasal, intermediate and superficial (Fig. 3 ) in the present study. The parabasal cells were small round cells with a high nuclear to cytoplasmic ratio and can be seen clearly in clusters when stained with methylene blue. The intermediate cells varied in size and shape as some can be oval with prominent nucleus and others polygonal with lesser nucleus to cytoplasmic ratio. These cells were clearly shown with the Papanicolaou stain than other stains. The superficial cells were the largest of all epithelial cells in the present study and were polygonal and appeared as either flat or rolled up in shape. These cells were better visible with the Wright-Giemsa stain.

3. Neutrophils. The neutrophils were small round cells with mono and polymorph nuclear leucocytes. All four stains were able to show the neutrophils very clear whether in clusters or singly (Fig. 4). The methylene blue gave better definition of neutrophils at the same magnification.
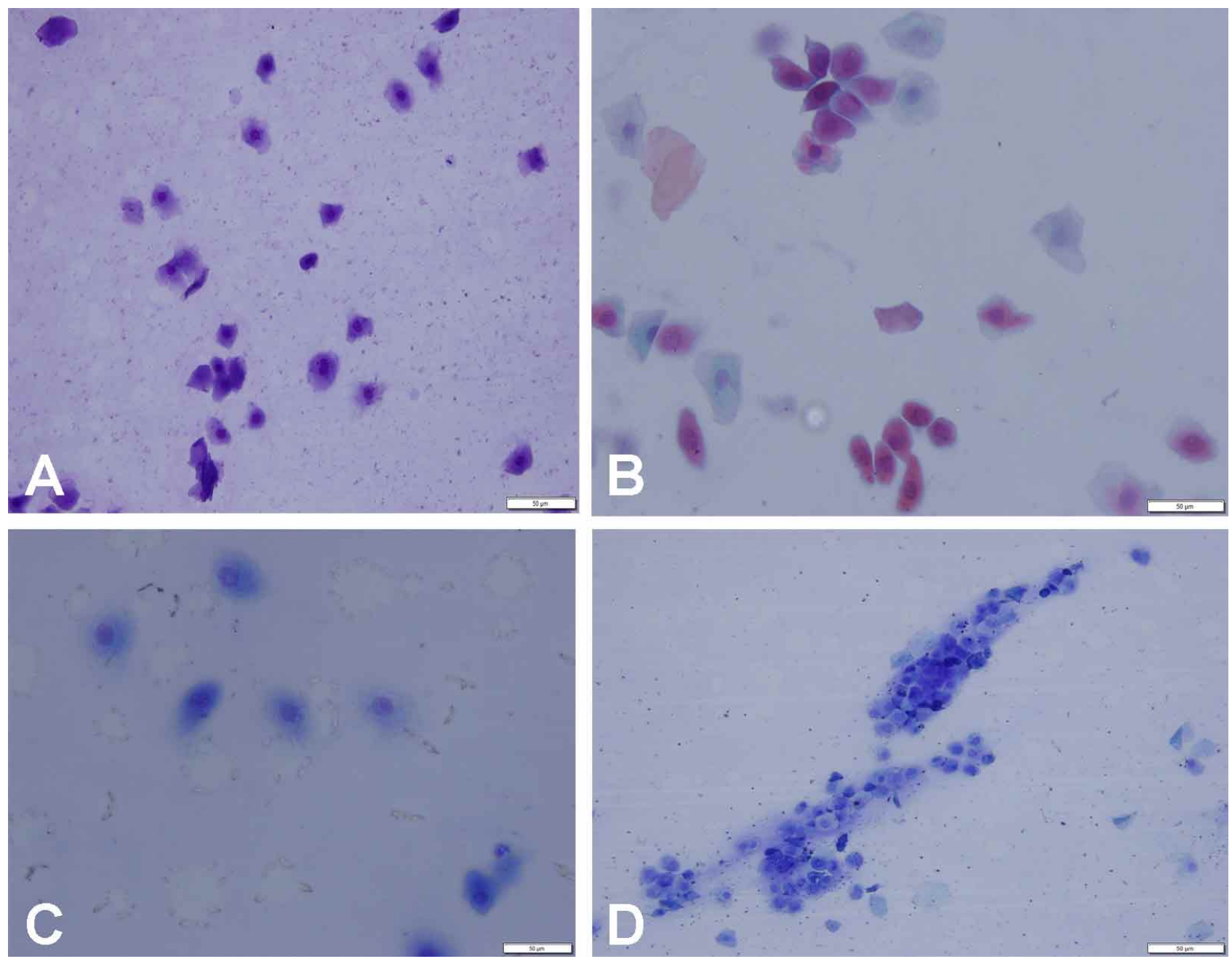

Fig. 3. Epithelial cells. Wright's Giemsa stain (A), Papanicolaou (B), Toluidine blue (C) and Methylene blue (D). Superficial cells are seen in (A), intermediate are clearly seen in (B) and parabasal cells in cluster (D). 

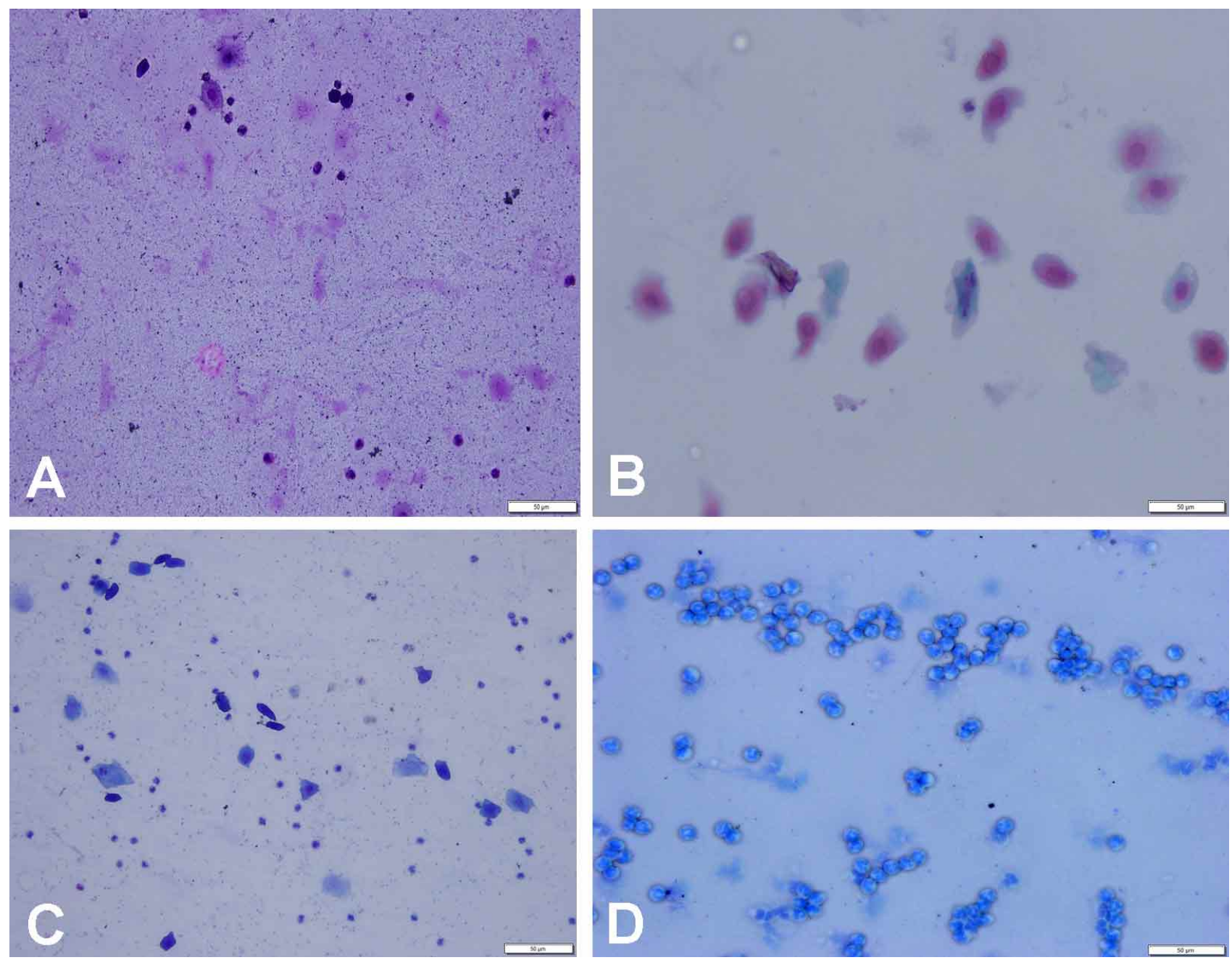

Fig. 4. Neutrophils for the Wrights Giemsa stain (A), Papanicolaou (B), Toluidine blue (C) and Methylene blue (D). The neutrophils may be spaced out, single or clumped.

Description of Stages of Oestrus in Sprague-Dawley rats with various stains. The following were the cytological detail of the normal oestrus cycle of female Sprague-Dawley rats observed in the present study.

Proestrus. This stage showed a predominance of small round nucleated cells with uniform shape. The cells were appeared either in clusters or individually as seen when stained with Pap stain (Fig. 5).

Oestrus. This stage was characterized by a progressive shedding of cornified squamous epithelial cells that lack visible nucleus, were irregular in shape and showed granular cytoplasm as shown with Wright-Giemsa and Methylene blue stain. The presence of bacteria was also be seen clearly in this stage with methylene blue stain (Fig. 5).
Metestrus. This stage showed a mixture of all major cell types, neutrophils, cornified and nucleated cells as shown with toluidine blue stain (Fig. 5).

Diestrus. This stage depicted a predominance of neutrophils as shown with methylene blue stain (Fig. 5).

\section{DISCUSSION}

The anucleated cornified cells were prominent in all four stains performed in this study. Various shades of orange, pink and blue associated with the level of cornification were observed from the Papanicolaou stain. The parabasal cells, with a high nuclear to cytoplasmic ratio were clearly shown in clusters with the use of methylene blue when compared 

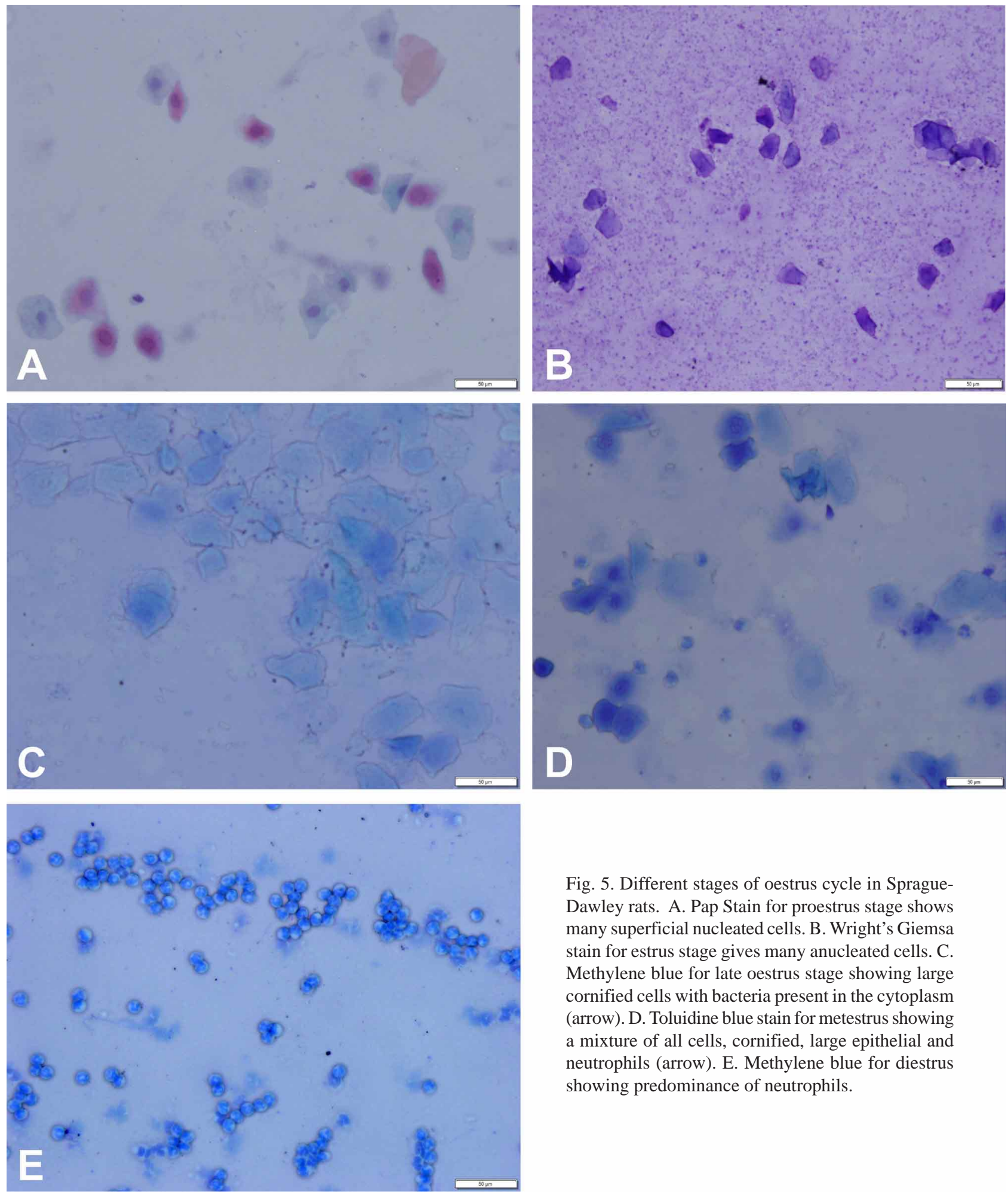

Fig. 5. Different stages of oestrus cycle in SpragueDawley rats. A. Pap Stain for proestrus stage shows many superficial nucleated cells. B. Wright's Giemsa stain for estrus stage gives many anucleated cells. C. Methylene blue for late oestrus stage showing large cornified cells with bacteria present in the cytoplasm (arrow). D. Toluidine blue stain for metestrus showing a mixture of all cells, cornified, large epithelial and neutrophils (arrow). E. Methylene blue for diestrus showing predominance of neutrophils.

with the toluidine blue. The intermediate cells were noticeably visible with lesser nucleus to cytoplasmic ratio in the Papanicolaou stain. The superficial cells were very clear in the
Wright's-Giemsa stain. The neutrophils were visible regardless of the staining method. In the present study bacteria was clearly evident in both the toluidine blue and methylene blue. 
The Papanicolaou stain is considered a multi-chromatic classical stain that provides colouring of differential acidophilic and basophilic cells with sharp nuclear staining. It stains the cytoplasm of cells with various shades based on the level of cornification. It requires fixation and the staining protocol takes 25-30 min. (Ochei \& Kolhatkar; Cora et al.; Choudhary et al., 2012). Though the most recommended stain in vaginal cytology is the Pap stain based on the level of cellular details. The wet fixation promotes the clarity of cellular details in this stain. The wet fixation sharpens the nuclear outlines and any unusual chromatin patterns while air drying amplifies the cell for more accurate evaluation. This happens because air drying influences the structure of the nuclear chromatin which makes it ideal for the comparison of normal and malignant cells. Due to this fact, it is widely used in traditional gynaecological cytology and for screening of cervical cancer in humans. But, to assess the stages of oestrous cycle in rats with cytology did not warrant the level of details depicted by the pap stain. In addition, the cost and duration of other stains make them more preferable than the Pap stain for the present study.

The Wright-Giemsa stain, a modified Romanowsky stain is the combination of methylene blue with eosin red. The generally accepted staining scheme produce purple chromatin, blue leucocyte cytoplasm, purple neutrophils, pink-red cells and purple granules. This occurs as a result of acid and base dying in poly cations and poly anions giving rise to blue staining of ribosome rich cytoplasm (Horobin, 2011). This stain is the most preferred stain for dried smears as they allow better estimation of cell-nuclear ratio with enhanced cytoplasmic details. This stain is used for nongynaecological purposes such as staining of sputum and malignant cells (Conn, 1961; Lillie, 1969; Ochei \& Kolhatkar) and for vaginal infections and inflammatory conditions. The advantage of this stain is that there is no special fixation requirement and generally the time taken varies from 10-15 minutes depending on the strength of the stain. But this is a major limitation as staining time can result in observable wrong colours. The results are also dependent on the method of sample collection. In vaginal cytology, the major limitation of this stain is the inability to highlight keratinization occurring in the cytoplasm (Krafts \& Pambuccian, 2011) which was evident in the present study also.

Toluidine blue which is considered a basic metachromatic dye with high affinity towards acidic tissues, stains the nuclei dark blue and the polysaccharides violet because of its strong binding capacity towards the nuclear material (DNA) in the nucleus and (RNA) in the cytoplasm (Sridharan \& Shankar, 2012). This stain is very useful in detecting vulvar cancer and lacerations in rape victims (McCauley, 1987). A similar stain to toluidine blue is methylene blue, a cationic stain that stains negatively charged components of cells and has been considered good in the identification of bacteria and cell structure (Bancroft \& Stevens; Turgeon, 2005). The advantages of both the staining methods are that they are very simple, less time consuming, do not require any special fixation and they show evidence of bacteria clearly as seen in this present study. Yet the poor quality of staining due to improper staining time and deteriorated reagents are very common among these two stains.

In assessing the stages of oestrous cycle in rats, the toluidine blue and methylene blue will be very effective if proper staining time and proper reagents were used when the time and cost is considered. Additionally, at present, unstained slides are also considered effective when examined directly under the microscope and is considered reliable and less consuming (Yener et al., 2007) but it needs little expertise.

\section{CONCLUSION}

All four stains have their own unique properties with many similarities and few varying limitations. The various stains used in this study as seen can all be used in identifying the various cell types and stages of the oestrus cycle. However, the choice of staining depends mainly on the outcome desired as it will differ for clinical and research purposes. The cellular detail of interest, the time, cost and availability will all play an important role in the choice of stain.

MOHAMMED, S. \& SUNDARAM, V. Estudio comparativo de los métodos de tinción metacromática en la evaluación de los tipos de células exfoliativas durante el ciclo estral en ratas SpragueDawley de laboratorio. Int. J. Morphol., 36(3):962-968, 2018.

RESUMEN: El presente estudio tuvo como objetivo comparar las tinciones metacromáticas comúnmente utilizadas, Wright's-Giemsa, azul de toluidina, azul de metileno y tinción de Papanicolaou, en la evaluación de los tipos de células del ciclo estral en ratas. El estudio se realizó en ocho ratas hembras SpragueDawley, con edades entre 8 y 9 semanas, y se usaron hisopos vaginales de algodón para preparar portaobjetos. Los diferentes tipos de células se compararon por sus características morfológicas y claridad en las cuatro tinciones. La aplicación, ventajas y limitaciones de todas las tinciones fueron discutidas. Se concluye que la selección de la tinción más efectiva en la evaluación de la citología vaginal depende de su uso, es decir, clínico o de investigación, el detalle celular de interés, tiempo, costo y disponibilidad.

PALABRAS CLAVE: Papanicolaou; Wright-Giemsa; Azul de metileno; Azul de toluidina; Citología vaginal. 


\section{REFERENCES}

Bancroft, G. D. \& Stevens, A. Theory and Practice of Technique. $4^{\text {th }}$ ed. New York, Churchill Livingstone Inc., 1996.

Choudhary, P.; Sudhamani, S.; Pandit, A. \& Kiri, V. Comparison of modified ultrafast Papanicolaou stain with the standard rapid Papanicolaou stain in cytology of various organs. J. Cytol., 29(4):241-5, 2012.

Conn, H. J. Biological Stains: A Handbook on the Nature and Uses of the Dyes Employed in the Biological Laboratory. $6^{\text {th }}$ ed. Baltimore, Williams and Wilkins, 1961.

Cora, M. C; Kooistra, L. \& Travlos, G. Vaginal cytology of the laboratory rat and mouse: Review and criteria for the staging of the estrous cycle using stained vaginal smears. Toxicol. Pathol., 43(6):776-93, 2015.

Horobin, R. W. How Romanowsky stains work and why they remain valuable - including a proposed universal Romanowsky staining mechanism and a rational troubleshooting scheme. Biotech. Histochem., 86(1):36-51, 2011.

Krafts, K. P. \& Pambuccian, S. E. Romanowsky staining in cytopathology: history, advantages and limitations. Biotech. Histochem., 86(2):82-93, 2011.

Lillie, R. D. H. J. Conn's Biological Stains: A Handbook on The Nature and Uses of the Dyes Employed in the Biological Laboratory. $8^{\text {th }}$ ed. Baltimore, Williams and Wilkins, 1969.

Long, J. A. \& Evans, H. M. The Oestrous Cycle in the Rat and its Associated Phenomena. Berkeley, University of California Press, 1922.

McCauley, J.; Guzinski, G.; Welch, R.; Gorman, R. \& Osmers, F. Toluidine blue in the corroboration of rape in the adult victim. Am. J. Emerg. Med.,5(2):105-8, 1987.

Ochei, J. \& Kolhatkar, A. Medical Laboratory Science: Theory and Practice. New York, McGraw-Hill Education, 2000. pp.513-37.

Sridharan, G. \& Shankar, A. A. Toluidine blue: A review of its chemistry and clinical utility. J. Oral Maxillofac. Pathol., 16(2):251-5, 2012.

Suvarna, K. S.; Christopher, L. \& Bancroft, J. Bancroft's Theory and Practice of Histological Techniques. $7^{\text {th }}$ ed. New York, Churchill Livingstone, 2012.

Turgeon, M.L. Clinical Hematology: Theory and Procedures. $4^{\text {th }}$ ed. Philadelphia, Lippincott Williams and Wilkins, 2005.

Yener, T.; Turkkani Tunc, A.; Aslan, H.; Aytan, H. \& Cantug Caliskan, A. Determination of oestrous cycle of the rats by direct examination: how reliable? Anat. Histol. Embryol., 36(1):75-7, 2007.

\author{
Corresponding author: \\ Dr. Venkatesan Sundaram \\ Department of Basic Veterinary Sciences \\ Faculty of Medical Sciences \\ The University of The West Indies \\ St. Augustine, Trinidad \\ TRINIDAD AND TOBAGO
}

Email: mailto:drvenkat1971@gmail.com

Received: 24-01-2018

Accepted: 05-03-2018 